\title{
Process Optimization Studies of Congo Red Dye Adsorption onto Magnesium Aluminium Layered Double Hydroxide Using Response Surface Methodology
}

\author{
Van Tan Lam ${ }^{1,2}$, To-Uyen T. Dao ${ }^{3,4 *}$, Hong-Tham T. Nguyen ${ }^{2,3}$, \\ Duyen Thi Cam Nguyen ${ }^{2,3}$, Hanh T.N. Le ${ }^{5}$, Huong T.T. Nguyen ${ }^{3}$, Sy Trung Do ${ }^{6}$, \\ Ho Huu Loc ${ }^{2}$, Trinh Duy Nguyen ${ }^{2,3 * *}$
}

${ }^{1}$ Ben Tre's Department of Science and Technology, Ben Tre Province 86000, Vietnam

${ }^{2}$ NTT Hi-Tech Insitute, Nguyen Tat Thanh University, 300A Nguyen Tat Thanh, District 4, Ho Chi Minh City, Vietnam

${ }^{3}$ Center of Excellence for Green Energy and Environmental Nanomaterials (CE@GrEEN),

Nguyen Tat Thanh University, 300A Nguyen Tat Thanh, District 4, Ho Chi Minh City, Vietnam

${ }^{4}$ Department of Chemical Engineering, HCMC University of Technology, VNU-HCM, Ho Chi Minh City, Vietnam

${ }^{5}$ Institute of Hygiene and Public Health, 159 Hung Phu, Ward 8, District 8, Ho Chi Minh City, 700000, Vietnam

${ }^{6}$ Institute of Chemistry, Vietnam Academy of Science and Technology,

18 Hoang Quoc Viet, Cau Giay District, Hanoi City, Vietnam

Received: 17 January 2020

Accepted: 24 April 2020

\begin{abstract}
Textile and dyeing industry have a large production network and rapid growth. However, the use of large quantities of industrial dyes and untreated wastewater pollutes the soil and water environment and directly affects human, animal and plant health. Therefore, the most important thing is to develop new adsorbents with high removal efficiency and fast separation rate to handle a large amount of waste. In this study, Mg/Al LDHs materials were successfully synthesized by hydrothermal method. The SEM images, which can be observed from the low-magnification, show that Mg/Al LDHs have morphology similar to hierarchical flower. In addition, strong intensities in XRD result indicates the high purity and good crystallization in LDH-type materials. Three factors affecting Congo red (CR) adsorption capacity include: Influence of CR solution concentration, effect of solution $\mathrm{pH}$ and reaction time conducted by response surface method (RSM) to find the optimal conditions for CR removal. The experimental results showed that at $\mathrm{CR}$ concentration $52.32 \mathrm{mg} / \mathrm{L}$, the reaction time of 118 minutes and $\mathrm{pH} 5.8$ obtained the
\end{abstract}

*e-mail: touyen2407@gmail.com

**e-mail:ndtrinh@ntt.edu.vn 
maximum CR adsorption capacity of $42.57 \mathrm{mg} / \mathrm{g}$. Through the surface response method (RSM) shows the optimization of the influential conditions.

Keywords: layer double hydroxide, Congo Red Dye, RSM, adsorption, removal

\section{Introduction}

Over the past decades, efficient adsorbent materials, which often include alginate, activated carbon, denatured chitin, zeolite, and bentonite have been studied to remove dyes from the aqueous media [1-8]. However, the hydrotalcite materials have been receiving a lot of attentions from researchers mainly because of its wide application potential in many areas such as adsorption, catalysis, photochemistry, biomedical, sensor [9-11]. Indeed, for catalysis area, Yingqun Ma et al. recently employed transesterification of waste cooking oil to produce green and eco-friendly biodiesel using mixed methanol and ethanol as a fuel input [12]. In particular, the $\mathrm{Mg} / \mathrm{Al}$ hydrotalcite catalyst has been easily separated and recycled, indicating the high activity and performance. Hong Dinh Duong et al. created a morin-hydrotalcite complex, which plays a vital role in the selective detection of common ions including $\mathrm{HPO}_{4}^{2-}$ and $\mathrm{H}_{2} \mathrm{PO}_{4}^{-}$under the ratiometric fluorescence [13]. It is reported that its linear detection range was found to be quiet wide, from 0.01 to $0.2 \mathrm{mmol} / \mathrm{L} \mathrm{HPO}_{4}{ }^{2-}$. Very recently, Po-Hsiang Chang et al. have successfully synthesized calcined hydrotalcite (CHT) with high surface area $\left(202 \mathrm{~m}^{2} / \mathrm{g}\right)$ for high removal of perfluorooctanoic acid (1587 mg/g) and $\mathrm{pH}$ independent [14]. At the same trend, MgAlSn based hydrotalcite catalyzed photochemical degradation for the phenol compounds have been effectively proved via the study by Sonia Mancipe et al., which indicated the component of MgAlSn 15\% exhibited the best photoactivity ( $80 \%$ degradation yield) within 3 hours under visual light irritation. However, there have been limited applications in utilizing hydrotalcite, therefore, it is necessary to widen the strength of $\mathrm{Mg} / \mathrm{Al}$-based hydrotalcite for environmental remediation fieldIn general, the outstanding advantages of $\mathrm{Mg} / \mathrm{Al}$-based hydrotalcite material, for example, the porosity and specific surface area is relatively large, heat-stable, the ion exchange capacity in the interlayer leads to hydrotalcite materials capable of adsorption of anions organic and inorganic in water environment [15-19]. In terms of adsorption fields, there has been a wide range of publications which reported the use of $\mathrm{Mg} / \mathrm{Al}$ hydrotalcite for removal of pollutants with the promising outcomes. For example, Yu Chen et al. revealed that hydrotalcite modified bentonite could remove various contaminants such as heavy metals $\left(\mathrm{Pb}^{2+}\right.$ and $\left.\mathrm{Cu}^{2+}\right)$ and textile dyes (methyl orange) in water with outstanding adsorption capacities from 156.3 to $384.6 \mathrm{mg} / \mathrm{g}$ [20]. At the same trend, Hongguang Zhou et al. demonstrated that co-precipitation method-synthesized FeMnMg$\mathrm{LDH}$ removed efficiently lead (II) from wastewater
[21]. More highlighted, the authors found that the coexisting divalent cations could compete with $\mathrm{Pb}^{2+}$ ions, leading to a decrease in adsorption efficiency. In gas phase adsorption, the study by Shu Panxiang Chen et al. chemically modified the hydrotalcite material with polyethylenimine to obtain an optimum carbon dioxide uptake capacity up to $1.723 \mathrm{mmol} / \mathrm{g}$ [22]. When hydrotalcite was modified with potassium at elevated temperature, Xuancan Zhu et al. proved the role of high pressure in $\mathrm{CO}_{2}$ adsorption [23].

It is acknowledged that textile and dyeing industry has a large production network, many categories, goods and fast growth [24-26]. However, a large amount of industrial dyes and untreated wastewater has been discharging into the environment, directly causing serious pollution issues towards human, anima, and plant health. Congo Red (CR) belongs to the azo dye, derivated from 1-naphthalene sulfonic acid, which is commonly used today [27]. They are relatively durable, chemically non-biodegradable when released to the aqueous environment. Exposure to Congo Red can be harmful to human health, when inhalation of CR can cause respiratory irritation, sore throat, shortness of breath and chest pain [28, 29]. Some symptoms can be seen after swallowing, it may cause stomach and intestinal pain, as accumulated in the stomach causing cancer, as wearing clothes with CR residues for a long time can lead to skin cancer [30]. More seriously, CR in wastewater can be a major reason for hampering the solar light sources, resulting a strong depletion of the photosynthetic performance of aqueous creatures [30]. Therefore, it is necessary to find effective methods and develop inexpensive adsorbent materials to remove dyes in aqueous media before releasing natural water [31-35]. In the world, many authors paid much attention to dyes remediation. Ageetha Vanaamudan et al. found that the use of hydrotalcite under the mild conditions of adsorption process gave promising results in reactive blue 21 and reactive red 141 adsorptive removal, which major interactions between dyes and hydrotalcite have been proposed as electrostatic, hydrogen bonding and van der Waals interactions [36]. Feifei Chen et al. successfully used synergistic adsorption and degradation strategies via CoFe-based LDHs to remove up to $95.6 \%$ Red 23 after $30 \mathrm{~min}$ only [37]. Amaranth azo dyes have also been removed by MgAl-LDHs while the recyclability of the used adsorbents was well-performed [38]. Meanwhile, Dong Yuan et al. reported a favorable way to treat methyl orange quickly (after $40 \mathrm{~min}$ ) and recycle efficiently (up to 4 times) using $\mathrm{ZnMgAl}$ hydrotalcite [39]. In the previous studies, the most common synthesis technique involves co-precipitation at constant or variable $\mathrm{pH}$. 
However, the downsides of these method are chemical segregations as well as heterogeneous crystallization. Thus, the technique requires very rigorous experimental conditions to synthesize LDHs. Meanwhile, hydrothermal treatment has emerged recently and received a great deal of attention because of the benefits it brings, including improved electrical and magnetic properties of the as-synthesized metal and in turn improved compatibility with other materials [40]. In addition, urea decomposition by hydrolyzing urea using water solvent creates an alkaline environment, leading to well-crystallized LDHs. Moreover, this combination considered as a green method with lowcost and high efficiency [41, 42]. Thus, in present study, we used solutions of aluminum and magnesium, under the urea decomposition and hydrothermal treatment to synthesis $\mathrm{Mg} / \mathrm{Al} \mathrm{LDHs}$. Adsorption is considered as a highly appropriate technique because this kind of conventional method features a range of favorability such as easy performance without any toxic additional substances [43-45], as a result, many researchers paid much attention to it $[46,47]$. To study the removal of dyes in water, effect of factors (concentration, adsorbent dosage, $\mathrm{pH}$, contact time, etc.) needs to be investigated vigorously. Among the tools used to optimize these parameters, response surface methodology (RSM) presents a powerful approach when it can resolve with a response or a set of responses dependent on input variables [48-50]. In particular, the main advantages of RSM may be the reduction of the total number of experimental runs, high confidence level for predictions, easy observation in optimization steps, allowing simple procedures including design spaces and single factor tests. With such good availability, this study focused on synthesizing $\mathrm{Mg} / \mathrm{Al} \mathrm{LDHs}$ materials and studying their adsorption properties to remove CR dyes. The conditions affecting adsorption capacity include initial concentration, $\mathrm{pH}$ value and reaction time studied by the $\mathrm{RSM}$ approach. The characterization of $\mathrm{Mg} / \mathrm{Al} \mathrm{LDHs}$ particles was employed by using X-Ray Diffraction (XRD), and Scanning Electron Microscope (SEM).

\section{Materials and Method}

Materials

Magnesium chloride hexahydrate $\left(\mathrm{MgCl}_{2} \cdot 6 \mathrm{H}_{2} \mathrm{O}\right.$ (98\%)), Aluminum chloride hexahydrate $\left(\mathrm{AlCl}_{3} \cdot 6 \mathrm{H}_{2} \mathrm{O}\right.$
(97\%)) and urea (99\%) were purchased from Sigma Aldrich.

\section{Characterization of $\mathrm{Mg} / \mathrm{Al} \mathrm{LDHs}$}

The crystal structure of the material is confirmed by X-ray diffraction (XRD) on the D8 Advance Bruker, using $\mathrm{Cu} \mathrm{K} \alpha$ stimulation with a scanning rate of $0.030 \%$ in the $2 \theta$ region from $10-70^{\circ}$. Crystal morphology of the material was observed through scanning electron microscope (Scanning Electron Microscope, SEM, JSM 7401F, Jeol). The concentration of CR dye was measured via Tomos V-1100 UV/Vis sepetroparameter at wavelength of $500 \mathrm{~nm}$.

\section{Synthesis of Mg-Al LDHs}

Materials $\mathrm{Mg} / \mathrm{Al} \mathrm{LDHs}$ were synthesized by hydrothermal method in three steps: $1 / \mathrm{Mix} \mathrm{AlCl}_{3} \cdot 6 \mathrm{H}_{2} \mathrm{O}$ $(8 \mathrm{mmol}), \mathrm{MgCl}_{2} \cdot 6 \mathrm{H}_{2} \mathrm{O}(4 \mathrm{mmol})$ and urea $(128 \mathrm{mmol})$ were dissolved in $60 \mathrm{~mL}$ distilled water in 30 minutes. $2 /$ The mixture is put into Telflon tube with stainless steel protective cover and heated at $100^{\circ} \mathrm{C}$ for 24 hours. $3 /$ The precipitate obtained after hydrothermal process (white powder) was washed several times with distilled water and ethanol until $\mathrm{pH}=7$ and dried at $80^{\circ} \mathrm{C}$.

\section{Experimental Section}

The CR adsorption procedure on $\mathrm{Mg} / \mathrm{Al} \mathrm{LDHs}$ was carried out as follows: An amount of $40 \mathrm{mg}$ of the adsorbent was mixed with $100 \mathrm{~mL}$ of $\mathrm{CR}$ solution in the concentration range 33.18-66.81 and the $\mathrm{pH}$ solution changed from 4.31 to 7.68 in the $250 \mathrm{~mL}$ triangle flask. The adsorption solution is taken at different times and centrifuged for 10 minutes to separate the solution from the adsorbent. After that, the remaining dye concentration is determined by spectrophotometry at a wavelength of $500 \mathrm{~nm}$. The adsorption capacity of $\mathrm{Mg} / \mathrm{Al} \mathrm{LDHs}$ is calculated based on the concentration difference before and after the adsorption process according to the following equation:

$$
\mathrm{H}(\%)=\left(1-\frac{\mathrm{C}}{\mathrm{C}_{\mathrm{o}}}\right) * 100
$$

...where, $\mathrm{C}_{\mathrm{o}}$ and $\mathrm{C}_{\mathrm{e}}$ are the respectively initial and equilibrium dye concentrations $(\mathrm{mg} / \mathrm{L})$.

Table 1. Independent variables and their encoded levels.

\begin{tabular}{|c|c|c|c|c|c|c|c|c|}
\hline \multirow{2}{*}{ No } & \multirow{2}{*}{ Independent factors } & \multirow{2}{*}{ Unit } & \multirow{2}{*}{ Code } & \multicolumn{5}{|c|}{ Levels } \\
\cline { 5 - 9 } & & & & $-\alpha$ & -1 & 0 & +1 & $+\alpha$ \\
\hline 1 & pH of solution $(\mathrm{pH})$ & - & $\mathrm{A}$ & 4.31 & 5 & 6 & 7 & 7.68 \\
\hline 2 & Concentration $\left(\mathrm{C}_{\mathrm{o}}\right)$ & $\mathrm{g} / \mathrm{L}$ & $\mathrm{B}$ & 33.18 & 40 & 50 & 60 & 66.38 \\
\hline 3 & Time & $\min$ & $\mathrm{C}$ & 86.36 & 100 & 120 & 140 & 153.36 \\
\hline
\end{tabular}




\section{Experimental Design with RSM}

Surface response method is used to optimize the conditions that affect the CR removal efficiency in aqueous solution. The CCD matrix is designed to evaluate the compatibility of experimental data and the variables affecting the removal efficiency of $\mathrm{CR}$ are presented in Table 1.

The 20 experiments were set up by the central composite design with five levels including the low $(-1)$, high $(+1)$ and rotatable $( \pm \alpha)$.

\section{Results and Discussion}

\section{Characteristic Analysis of Mg-Al LDHs Structure}

The XRD diffraction pattern of the sample $\mathrm{Mg} / \mathrm{Al}$ LDHs is shown in Fig. 1. As can be seen from Fig. 1, the material sample shows the characteristic structure of hydrotalcite, which is already known with typical peaks at $2 \theta$ degrees including $11.71^{\circ}(101), 23.4^{\circ}(002), 35.2^{\circ}$ (211) and a wide range of weak diffraction peaks at $2 \theta=39.75^{\circ}(300)$. In general, the structure of the material highly corresponds to a previous report on

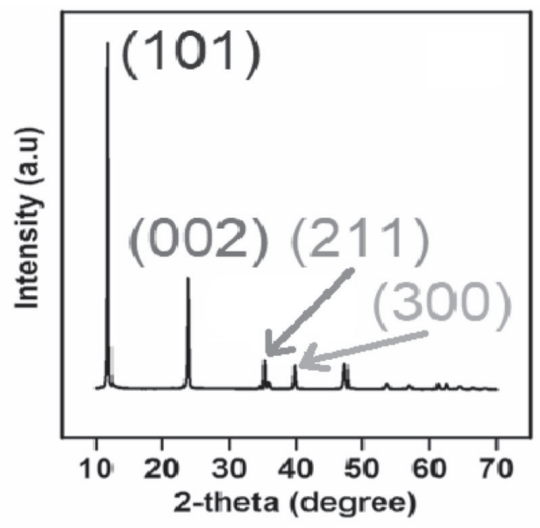

Fig. 1. XRD diagram profile of $\mathrm{Mg} / \mathrm{Al} \mathrm{LDHs}$ material.

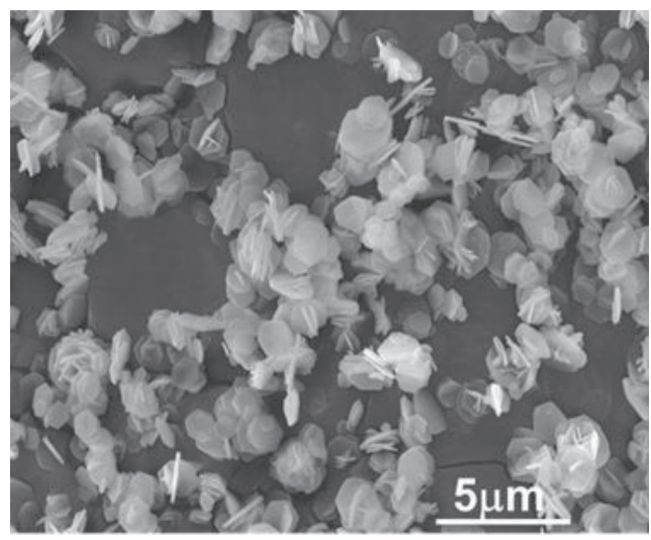

Fig. 2. SEM image profile of $\mathrm{Mg} / \mathrm{Al} \mathrm{LDHs}$ material. hydrotalcite [51]. Therefore, the $\mathrm{Mg} / \mathrm{Al} \mathrm{LDHs}$ has been successfully synthesized.

To observe the surface morphology of $\mathrm{Mg} / \mathrm{Al}$ LDHs, the scanning electron microscope technique was adopted. Fig. 2 shows the typical morphology of hydrotalcite material at scale $5.0 \mu \mathrm{m}$. As observed, the material surface consists of many semi-hexagonal structures like flower and uniform with $2-3 \mathrm{~mm}$ diameter. Javier et al. also reported the same surface morphology of hydrotalcite materials in the route synthesized by hydrothermal method [52]. From the SEM images and the XRD result, it is clearly shown that using chloride salt led to better crystallization than the previous results of B. Wiyantoko et al., which involved the use of carbonate salt [53].

\section{Optimization Model}

The interaction of three independent variables includes: concentration of $\mathrm{CR}$ solution, solution $\mathrm{pH}$ and reaction time to $\mathrm{CR}$ adsorption capacity is presented in Table 2. Results show that the removal efficiency of $\mathrm{CR}$ is affected by independent variables. When these parameters change, it will affect adsorption efficiency. To determine the variables in the proposed model that are statistically significant, the p-value of the regression equation is significant with the $1 \%$ level for the quadratic model described as follows by equation:

$$
\begin{gathered}
\mathrm{H}(\%)=38.74-1.56 \mathrm{~A}+2.37 \mathrm{~B}+0.3133 \mathrm{C} \\
-0.2765 \mathrm{AB}+0.5045 \mathrm{AC}+0.2191 \mathrm{BC} \\
-4.37 \mathrm{~A}^{2}-5.18 \mathrm{~B}^{2}-2.65 \mathrm{C}^{2}
\end{gathered}
$$

Results of ANOVA variance analysis were used to evaluate the correlation of the influential variables according to quadratic polynomial equation. The quality of the proposed model is evaluated by the correlation coefficient $\mathrm{R}^{2}$ and the statistical significance of the model is confirmed by trials. With a large F-value and a small P-value with a low variance coefficient (CV), the proposed model is considered statistically significant (95\%) [54]. ANOVA analysis results presented in Table 3 show that the proposed model is statistically significant because of the achieved standards with $\mathrm{F}=30.52 ; \mathrm{P}<0.05 ; \mathrm{CV}(\%)=5.48$. Furthermore, the $\mathrm{R}^{2}$ correlation coefficient is relatively high $\left(\mathrm{R}^{2}=0.9649\right)$, suggesting that a significant proportion $(96.49 \%)$ of the total variation can be explained by experimental models.

In addition, the proposed model is considered consistent with the balance calculated randomly and presented in Fig. 3. It is clear that the data points correspond to the test and predictive values distributed linearly in a straight line, indicating the high reliability between experimental and predicted data [55, 56]. More importantly, Fig. 4 shows the random experiments run without any trend or diagnosis, suggesting the independence between the experimental value and runs. 
Table 2. Matrix of observed and predicted values for CR adsorption capacity.

\begin{tabular}{|c|c|c|c|c|c|c|c|c|c|c|c|}
\hline \multirow{2}{*}{ Run } & \multicolumn{3}{|c|}{ Independent factors } & \multirow{2}{*}{$\frac{\text { Actual }}{(\mathrm{mg} / \mathrm{g})}$} & \multirow{2}{*}{$\frac{\text { Predicted }}{(\mathrm{mg} / \mathrm{g})}$} & \multirow{2}{*}{ Run } & \multicolumn{3}{|c|}{ Independent factors } & \multirow{2}{*}{$\frac{\text { Actual }}{(\mathrm{mg} / \mathrm{g})}$} & \multirow{2}{*}{$\frac{\text { Predicted }}{(\mathrm{mg} / \mathrm{g})}$} \\
\hline & A & $\mathrm{B}$ & $\mathrm{C}$ & & & & A & B & $\mathrm{C}$ & & \\
\hline 1 & 5 & 40 & 100 & 26.25 & 26.50 & 11 & 6 & 33.18 & 6 & 20.89 & 20.12 \\
\hline 2 & 7 & 40 & 100 & 22.41 & 22.92 & 12 & 6 & 66.81 & 6 & 30.01 & 28.08 \\
\hline 3 & 5 & 60 & 100 & 30.96 & 31.35 & 13 & 6 & 50 & 6 & 32.33 & 31.77 \\
\hline 4 & 7 & 60 & 100 & 25.32 & 26.66 & 14 & 6 & 50 & 6 & 32.86 & 30.71 \\
\hline 5 & 5 & 40 & 140 & 23.86 & 24.43 & 15 & 6 & 50 & 6 & 37.99 & 38.74 \\
\hline 6 & 7 & 40 & 140 & 21.34 & 22.86 & 16 & 6 & 50 & 6 & 38.57 & 38.74 \\
\hline 7 & 5 & 60 & 140 & 28.75 & 30.15 & 17 & 6 & 50 & 6 & 39.66 & 38.74 \\
\hline 8 & 7 & 60 & 140 & 25.82 & 27.48 & 18 & 6 & 50 & 6 & 38.49 & 38.74 \\
\hline 9 & 4.31 & 50 & 120 & 29.64 & 29.02 & 19 & 6 & 50 & 6 & 39.81 & 38.74 \\
\hline 10 & 7.68 & 50 & 120 & 25.84 & 23.76 & 20 & 6 & 50 & 6 & 37.48 & 38.74 \\
\hline
\end{tabular}

Table 3. ANOVA for the CR removal models.

\begin{tabular}{|c|c|c|c|c|c|c|}
\hline Source & Sum of squares & Degree of freedom & Mean square & F-value & Prob. $>$ F & Comment \\
\hline Model & 763.87 & 9 & 84.87 & 30.52 & $<0.0001^{\mathrm{s}}$ & $\mathrm{SD}=1.67$ \\
\hline$x_{1}$ & 33.33 & 1 & 33.33 & 11.98 & $0.0061^{\mathrm{s}}$ & Mean $=30.41$ \\
\hline$x_{2}$ & 76.51 & 1 & 76.51 & 27.51 & $0.0004^{\mathrm{s}}$ & $\mathrm{CV}(\%)=5.48$ \\
\hline$x_{3}$ & 1.34 & 1 & 1.34 & 0.4820 & $0.5033^{\mathrm{n}}$ & Press $=184.88$ \\
\hline$x_{1}{ }^{2}$ & 275.02 & 1 & 275.02 & 98.89 & $<0.0001^{\mathrm{s}}$ & $\mathrm{R}^{2}=0.9649$ \\
\hline$x_{2}{ }^{2}$ & 386.41 & 1 & 386.41 & 138.94 & $<0.0001^{\mathrm{s}}$ & $\mathrm{R}_{(\text {adj. } .}=0.9333$ \\
\hline$x_{3}{ }^{2}$ & 101.39 & 1 & 101.39 & 36.46 & $0.0001^{\mathrm{s}}$ & $\mathrm{AP}=15.7955$ \\
\hline$x_{1} x_{2}$ & 0.6117 & 1 & 0.6117 & 0.2199 & $0.6492^{\mathrm{n}}$ & \\
\hline$x_{1} x_{3}$ & 2.04 & 1 & 2.04 & 0.7322 & $0.4122^{\mathrm{n}}$ & \\
\hline$x_{2} x_{3}$ & 0.3842 & 1 & 0.3842 & 0.1381 & $0.7179^{\mathrm{n}}$ & \\
\hline
\end{tabular}

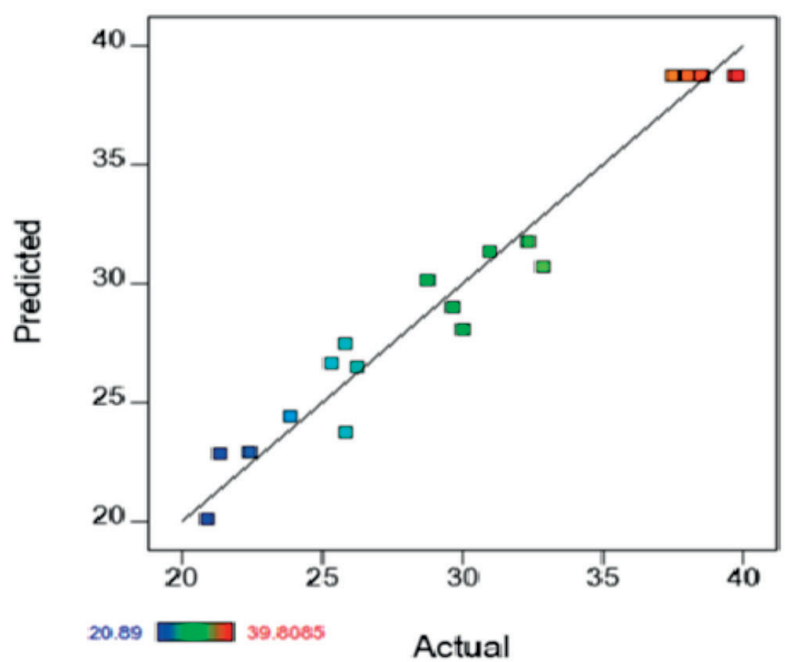

Fig. 3. Actual versus predicted plot for regression model of CR removal.

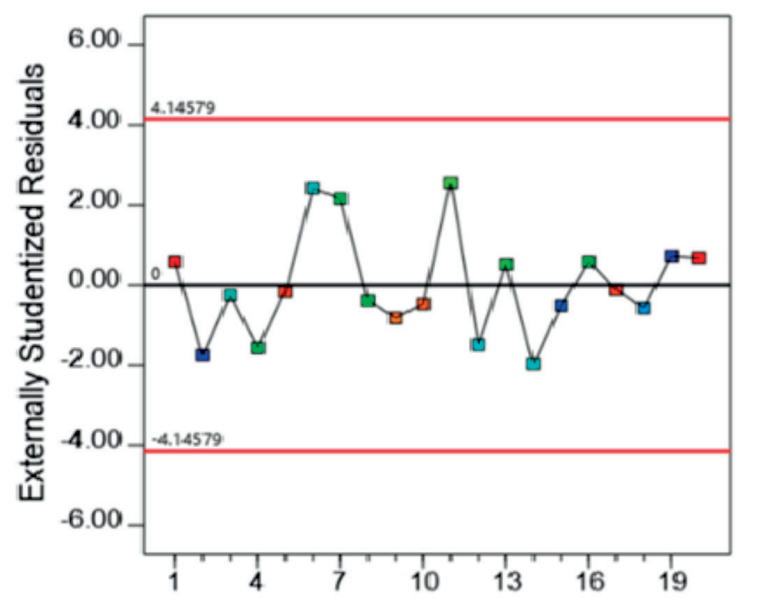

Run Number

Fig. 4. Externally studentized residuals versus run number for CR removal model. 

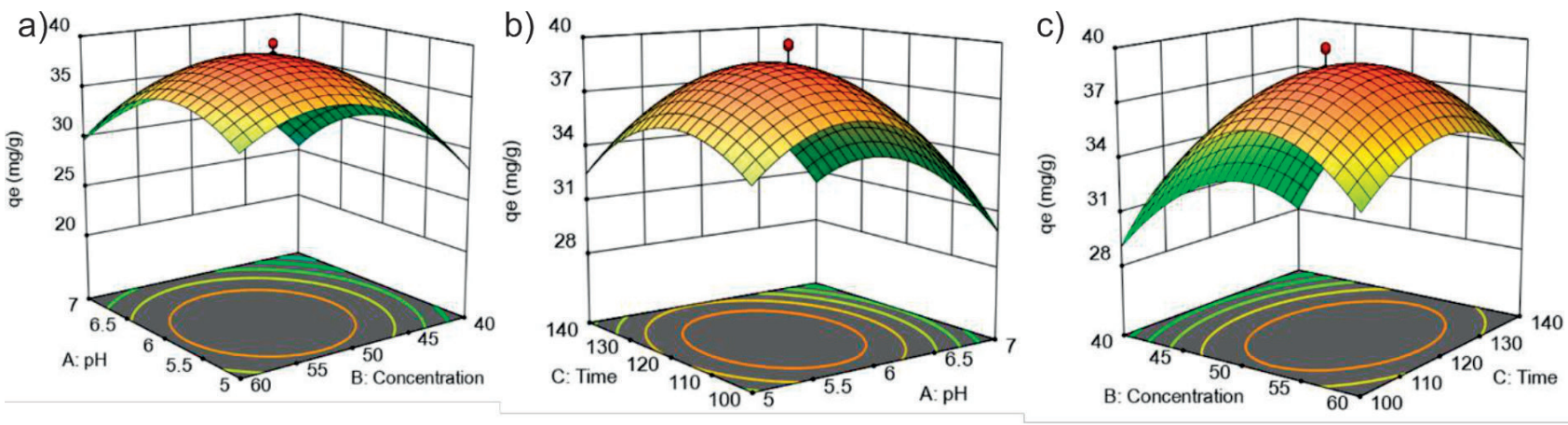

Fig. 5. The response surfaces (a-f) for regression model of the percentage of CR removal.

Table 4. Confirmation test.

\begin{tabular}{|c|c|c|c|c|c|c|c|}
\hline \multirow{2}{*}{ Sample } & \multirow{2}{*}{$\begin{array}{c}\mathrm{pH} \\
(-)\end{array}$} & \multirow{2}{*}{$\begin{array}{c}\text { Concentration } \\
(\mathrm{mg} / \mathrm{L})\end{array}$} & \multirow{2}{*}{$\begin{array}{c}\text { Time } \\
(\mathrm{min})\end{array}$} & \multicolumn{3}{|c|}{ Adsorption capacity $(\mathrm{mg} / \mathrm{g})$} & \multirow{2}{*}{ Desirability } \\
\cline { 5 - 7 } & & & & Predicted & Tested & Error & \\
\hline Mg-Al LDHs & 5.8 & 52.32 & 118 & 39.17 & 42.57 & 3.40 & 1.000 \\
\hline
\end{tabular}

Table 5. Comparative BET surface area and maximum adsorption capacity of various materials for CR adsorption.

\begin{tabular}{|c|c|c|c|c|}
\hline No. & Adsorbents & BET surface area $\left(\mathrm{m}^{2} / \mathrm{g}\right)$ & Maximum adsorption capacity $(\mathrm{mg} / \mathrm{g})$ & Ref. \\
\hline 1 & $\mathrm{Mg} / \mathrm{Al} \mathrm{LDHs}$ & - & 42.57 & This work \\
\hline 2 & Anilinepropylsilica xerogel & 150 & 22.62 & {$[65]$} \\
\hline 3 & NaBentonite & 25.7 & 35.84 & {$[66]$} \\
\hline 4 & Kaolin & 20.28 & 5.44 & {$[66]$} \\
\hline 5 & Zeolite & 8.31 & 40.4 & {$[66]$} \\
\hline 6 & Bentonite & 32 & 11.88 & {$[67]$} \\
\hline 7 & Kaolin & 168.8 & 7.08 & {$[68]$} \\
\hline 8 & Activated red mud & 20.7 & 6.72 & {$[69]$} \\
\hline 9 & Activated coir pitch & - & {$[70]$} \\
\hline
\end{tabular}

Therefore, the proposed model is consistent with the test data $[57,58]$.

The removal efficiency $\mathrm{CR}$ depends on three independent variables shown in Fig. 5(a-c). The interaction of concentration and $\mathrm{pH}$ solution is illustrated in Fig. 5a). It can be seen that increasing concentration solution and decreasing $\mathrm{pH}$ solution lead to increase the ability to eliminate CR. The interaction of reaction time and $\mathrm{pH}$ solution is shown in Fig. 5b). The adsorption of CR increases in the short contact time at low $\mathrm{pH}$ environment. Meanwhile, reducing contact time and increasing adsorbate concentration showed enhanced adsorbate adsorption capacity [59-61]. In theory, in low $\mathrm{pH}$ environment, the material surface is positively charged and tends to electrostatically link between functional groups on the surface of the material and negatively charged CR molecules [62]. Conversely, at a high $\mathrm{pH}$ solution there will be competition between
$\mathrm{OH}^{-}$and anions, which will impede the adsorption center on the surface of the CR capture material [63], [64]. Therefore, the effect of CR type tends to decrease at high $\mathrm{pH}$ solution.

By applying the RSM method, the maximum adsorption capacity is set at optimal conditions as shown in Table 4. Experimental results show that at CR solution $52.32 \mathrm{mg} / \mathrm{L}$, the reaction time is 118 minutes at $\mathrm{pH} 5.9$ have the maximum absorption capacity of $\mathrm{CR}$ is $42.57 \mathrm{mg} / \mathrm{g}$. The results show that the adsorption CR capacity is consistent with the predicted value, indicating the reliability of the proposed model.

These results are compared with those of previous studies (Table 5), showing the higher Qm values than porous adsorbents mentioned. Therefore, $\mathrm{Mg} / \mathrm{Al} \mathrm{LDHs}$ can be a promising candidate for the adsorption of CR in wastewater. 


\section{Conclusion}

The Mg-Al LDHs material synthesized by hydrothermal method is used as an effective adsorbent to remove $\mathrm{CR}$ from aqueous solution. Factors affecting adsorption efficiency are optimized by RSM method via three independent factors including initial concentration, contact time and $\mathrm{pH}$ of the solution. The quadratic equations developed to model the adsorption of the prepared $\mathrm{Mg} / \mathrm{Al} \mathrm{LDHs}$ sample were proved to be statistically significant. Adsorption capacity of CR reached $42.57 \mathrm{mg} / \mathrm{g}$ at optimal conditions: $\mathrm{C}_{\mathrm{i}}=52.32 \mathrm{mg} / \mathrm{L} ; \mathrm{pH}=5.8$; reaction time $118 \mathrm{~min}$. Through surface response method, which reasonably predicted the experimental values, the fitness of the suggested models was illustrated and selected conditions were shown to be influential to the desired outcome. These results contribute to further efforts in developing new ways of removing $\mathrm{CR}$ in aqueous media.

\section{Acknowledgements}

This research is funded by Foundation for Science and Technology; Development Nguyen Tat Thanh University, Ho Chi Minh City, Vietnam.

\section{References}

1. ABOLGHASEMI H. Adsorption Isotherm of Cephalexin Antibiotic Using Modified Walnut Shell, $8^{\text {th }}$ Int. Chem. Eng. Congr. Exhib. (IChEC, no. IChEC, 24, 2014.

2. TANG H., ZHOU W., ZHANG L. Adsorption isotherms and kinetics studies of malachite green on chitin hydrogels, J. Hazard. Mater., 209-210, 218, 2012.

3. DARMOGRAI G. et al., Study of Adsorption and Intercalation of Orange-Type Dyes into Mg-Al Layered Double Hydroxide, J. Phys. Chem. C, 119 (41), 23388, 2015.

4. KUMAR A., JENA H.M. High surface area microporous activated carbons prepared from Fox nut (Euryale ferox) shell by zinc chloride activation, Appl. Surf. Sci., 2015.

5. TRAN V.T., et al., Facile synthesis of manganese oxideembedded mesoporous carbons and their adsorbability towards methylene blue, Chemosphere, 2019.

6. TRAN V.T., et al., Tunable Synthesis of Mesoporous Carbons from $\mathrm{Fe}_{3} \mathrm{O}$ (BDC) 3 for Chloramphenicol Antibiotic Remediation, Nanomaterials, 9 (2), 237, 2019.

7. TRAN V.T., et al., Amino-functionalized MIL-88B(Fe)based porous carbon for enhanced adsorption toward ciprofloxacin pharmaceutical from aquatic solutions, Comptes Rendus Chim., 2019.

8. TRAN V.T., et al., Response surface methodologyoptimized removal of chloramphenicol pharmaceutical from wastewater using $\mathrm{Cu} 3$ (BTC)2-derived porous carbon as an efficient adsorbent, Comptes Rendus Chim., 22, 794, 2019.

9. SARFRAZ M., SHAKIR I. Recent advances in layered double hydroxides as electrode materials for high-performance electrochemical energy storage devices, J. Energy Storage, 13, 103, 2017.

10. GUPTA V.K., SUHAS Application of low-cost adsorbents for dye removal - A review, J. Environ. Manage., 90 (8), 2313, 2009.

11. GOH K.H., LIM T.T., DONG Z. Application of layered double hydroxides for removal of oxyanions: A review, Water Res., 42 (6-7), 1343, 2008.

12. MA Y., WANG Q., ZHENG L., GAO Z., WANG Q., MA $Y$. Mixed methanol/ethanol on transesterification of waste cooking oil using Mg/Al hydrotalcite catalyst, Energy, 107, 523, 2016.

13. DUONG H.D., JONG IL R. Ratiometric fluorescence sensors for the detection of $\mathrm{HPO}_{4}^{2-}$ and $\mathrm{H}_{2} \mathrm{PO}_{4}^{-}$using different responses of the morin-hydrotalcite complex, Sensors Actuators B Chem., 274, 66, 2018.

14. CHANG P.-H., JIANG W.-T., LI Z. Removal of perfluorooctanoic acid from water using calcined hydrotalcite - A mechanistic study, J. Hazard. Mater., 368, 487, 2019.

15. ZUBAIR M., DAUD, M. MCKAY G., SHEHZAD F., AL-HARTHI M.A. Recent progress in layered double hydroxides (LDH)-containing hybrids as adsorbents for water remediation, Appl. Clay Sci., 143 (January), 279, 2017.

16. ZHAO J. et al. Synthesis of functionalized MgAl-layered double hydroxides via modified mussel inspired chemistry and their application in organic dye adsorption, J. Colloid Interface Sci., 505, 168, 2017.

17. LIN S.T., TRAN H.N., CHAO H.P., LEE J.F. Layered double hydroxides intercalated with sulfur-containing organic solutes for efficient removal of cationic and oxyanionic metal ions, Appl. Clay Sci., 162 (June), 443, 2018.

18. RICHETTA M., MEZZI A., PIZZOFERRATO R. Preparation, intercalation, and characterization of nanostructured $(\mathrm{Zn}, \mathrm{Al})$ layered double hydroxides (LDHs), no. April, 1, 2018.

19. JIANG J.Q., ASHEKUZAMAN S.M. Preparation and evaluation of layered double hydroxides (LDHs) for phosphate removal, Desalin. Water Treat., 55 (3), 836, 2015.

20. CHEN Y. et al. Adsorption behavior of hydrotalcitelike modified bentonite for $\mathrm{Pb}^{2+}, \mathrm{Cu}^{2+}$ and methyl orange removal from water, Appl. Surf. Sci., 420, 773, 2017.

21. ZHOU H., JIANG Z., WEI S. A new hydrotalcite-like absorbent FeMnMg-LDH and its adsorption capacity for $\mathrm{Pb}^{2+}$ ions in water, Appl. Clay Sci., 153, 29, 2018.

22. CHEN S.P., SUN X., LUO X., LIANG Z. $\mathrm{CO}_{2}$ Adsorption on Premodified Li/Al Hydrotalcite Impregnated with Polyethylenimine, Ind. Eng. Chem. Res., 58 (3), 1177, Jan. 2019.

23. ZHU X., SHI Y., CAI N. High-pressure carbon dioxide adsorption kinetics of potassium-modified hydrotalcite at elevated temperature, Fuel, 207, 579, 2017.

24. VAN THINH P., et al. Process Optimization by Response Surface Methodology for Adsorption Congo Red Dye onto Exfoliated Graphite-Decorated $\mathrm{MnFe}_{2} \mathrm{O}_{4}$ Nanocomposite: Pivotal Role of Surface Chemistry, Processess, 2019.

25. NONG L.X., et al. Crystal violet degradation over BiVO4 photocatalyst under visible light irradiation, Chem. Eng. Commun., 1, Oct. 2019.

26. PHAM V.T., et al. Kinetics, Isotherm, Thermodynamics, and Recyclability of Exfoliated Graphene-Decorated $\mathrm{MnFe}_{2} \mathrm{O}_{4}$ Nanocomposite Towards Congo Red Dye, J. Chem., 2019, 2019. 
27. DASTKHOON M., GHAEDI M., ASFARAM A., AZQHANDI M.H.A., PURKAIT M.K. Simultaneous removal of dyes onto nanowires adsorbent use of ultrasound assisted adsorption to clean waste water: chemometrics for modeling and optimization, multicomponent adsorption and kinetic study, Chem. Eng. Res. Des., 124, 222, 2017.

28. LEI C., PI M., CHENG B., JIANG C., QIN J. Fabrication of hierarchical porous $\mathrm{ZnO} / \mathrm{NiO}$ hollow microspheres for adsorptive removal of Congo red, Appl. Surf. Sci., 435, 1002,2018

29. YU P., HU T., CHEN H.H., WU F., LIU H. Effective Removal of Congo Red by Triarrhena Biochar Loading with $\mathrm{TiO}_{2}$ Nanoparticles, Scanning, 2018, 2018.

30. TIAN C., FENG C., WEI M., WU Y. Enhanced adsorption of anionic toxic contaminant congo red by activated carbon with electropositive amine modification, Chemosphere, 208, 476, 2018

31. ZHANG B., DONG Z., SUN D., WU T., LI Y. Enhanced adsorption capacity of dyes by surfactant-modified layered double hydroxides from aqueous solution, J. Ind. Eng. Chem., 49 (2016), 208, 2017.

32. SOUSA C.G., RIBEIRO A.R., BARBOSA M.O., PEREIRA M.F.R., SILVA M.T. A review on environmental monitoring of water organic pollutants identified by EU guidelines, J. Hazard. Mater., 2017.

33. LI Y., NIE W., CHEN P., ZHOU Y. Colloids and Surfaces A: Physicochemical and Engineering Aspects Preparation and characterization of sulfonated poly (styrene-alt-maleic anhydride) and its selective removal of cationic dyes, Colloids Surfaces A Physicochem. Eng. Asp., 499, 46, 2016.

34. NASEEM K., FAROOQI Z.H., BEGUM R., IRFAN A. Removal of Congo red dye from aqueous medium by its catalytic reduction using sodium borohydride in the presence of various inorganic nano-catalysts: A review, J. Clean. Prod., 187, 296, 2018.

35. BING K., VAKILI M., AMINI B., EONG P., ZUHAIRI A., SALAMATINIA B. Adsorption of dyes by nanomaterials: Recent developments and adsorption mechanisms, Sep. Purif. Technol., 150, 229, 2015.

36. VANAAMUDAN A., CHAVADA B., P.P. Adsorption of reactive blue 21 and reactive red 141 from aqueous solutions onto hydrotalcite, J. Environ. Chem. Eng., 4 (3), 2617, 2016

37. CHEN F., WU X., BU R., YANG F. Co-Fe hydrotalcites for efficient removal of dye pollutants via synergistic adsorption and degradation, RSC Adv., 7 (66), 41945, 2017.

38. ABDELLAOUI K., PAVLOVIC I., BOUHENT M., BENHAMOU A., BARRIGA C. A comparative study of the amaranth azo dye adsorption/desorption from aqueous solutions by layered double hydroxides, Appl. Clay Sci., 143, 142, 2017.

39. YUAN D., ZHOU L., FU D. Adsorption of methyl orange from aqueous solutions by calcined $\mathrm{ZnMgAl}$ hydrotalcite, Appl. Phys. A, 123 (2), 146, 2017.

40. RAJ V. Heterojunction perovskite solar cells, Perovskite Photovoltaics Basic to Adv. Concepts Implement., 2, 323, 2018.

41. MOLANO-MENDOZA M., DONNEYS-VICTORIA D., MARRIAGA-CABRALES N., MUESES M.A., LI PUMA G., MACHUCA-MARTÍNEZ F. Synthesis of $\mathrm{Mg}-\mathrm{Al}$ layered double hydroxides by electrocoagulation, MethodsX, 5, 915, 2018

42. LIAO L., ZHAO N., XIA Z. Hydrothermal synthesis of $\mathrm{Mg}-\mathrm{Al}$ layered double hydroxides (LDHs) from natural brucite and $\mathrm{Al}(\mathrm{OH})_{3}$, Mater. Res. Bull., 47 (11), 3897, 2012.
43. TRAN V.T., et al. Effect of thermolysis condition on characteristics and nonsteroidal anti-inflammatory drugs (NSAIDs) absorbability of Fe-MIL-88B-derived mesoporous carbons, J. Environ. Chem. Eng., 7 (5), 103356, 2019.

44. TRAN V.T., et al. Application of Fe-based metal-organic framework and its pyrolysis products for sulfonamide treatment, Environ. Sci. Pollut. Res., 1, 2019.

45. TRAN V.T., et al., MIL-53 (Fe)-directed synthesis of hierarchically mesoporous carbon and its utilization for ciprofloxacin antibiotic remediation, J. Environ. Chem. Eng., 7 (1), 102881, 2019.

46. POORALHOSSINI J., ZANJANCHI M.A., GHAEDI M., ASFARAM A., AZQHANDI M.H.A. Statistical optimization and modeling approach for azo dye decolorization: Combined effects of ultrasound waves and nanomaterial-based adsorbent, Appl. Organomet. Chem., 32 (3), e4205, 2018.

47. KHAN R.J., SAQIB A.N.S., FAROOQ R., KHAN R., SIDDIQUE M. Removal of Congo Red from Aqueous Solutions by Spent Black Tea as Adsorbent, J. Water Chem. Technol., 40 (4), 206, 2018.

48. THUAN T.V., QUYNH B.T.P., NGUYEN T.D., HO V.T.T., BACH L.G. Response surface methodology approach for optimization of $\mathrm{Cu}^{2+}, \mathrm{Ni}^{2+}$, and $\mathrm{Pb}^{2+}$ adsorption using $\mathrm{KOH}$-activated carbon from banana peel, Surfaces and Interfaces, 6, 209, 2017.

49. TRAN V.T., BUI Q.T.P., NGUYEN T.D., THANH HO V.T., BACH L.G. Application of response surface methodology to optimize the fabrication of $\mathrm{ZnCl}_{2}$-activated carbon from sugarcane bagasse for the removal of $\mathrm{Cu}^{2+}$, Water Sci. Technol., 75 (9), 2047, 2017.

50. TRAN V.T., BUI Q.T.P., NGUYEN T.D., LE N.T.H., BACH L.G. A comparative study on the removal efficiency of metal ions $\left(\mathrm{Cu}^{2+}, \mathrm{Ni}^{2+}\right.$, and $\left.\mathrm{Pb}^{2+}\right)$ using sugarcane bagasse-derived $\mathrm{ZnCl} 2$-activated carbon by the response surface methodology, Adsorpt. Sci. Technol., 35 (1-2), 72, Sep. 2016.

51. HUANG P.P., CAO C.Y., WEI F., SUN Y.B., SONG W.G. MgAl layered double hydroxides with chloride and carbonate ions as interlayer anions for removal of arsenic and fluoride ions in water, RSC Adv., 5 (14), 10412, 2015.

52. PÉREZ-RAMÍREZ J., ABELLÓ S. Thermal decomposition of hydrotalcite-like compounds studied by a novel tapered element oscillating microbalance (TEOM): Comparison with TGA and DTA, Thermochim. Acta, 444 (1), 75, 2006

53. WIYANTOKO B., KURNIAWATI P., PURBANINGTIAS T.E., FATIMAH I. Synthesis and Characterization of Hydrotalcite at Different Mg/Al Molar Ratios," Procedia Chem., 17, 21, 2015.

54. BACH L.G., TRAN T.V., NGUYEN T.D., PHAM T.V., DO S.T. Enhanced adsorption of methylene blue onto graphene oxide-doped $\mathrm{XFe}_{2} \mathrm{O}_{4}(\mathrm{X}=\mathrm{Co}, \mathrm{Mn}, \mathrm{Ni})$ nanocomposites: kinetic, isothermal, thermodynamic and recyclability studies, Res. Chem. Intermed., 44 (3), 1661, 2018.

55. TRAN V.T., et al. Combined Minimum-Run Resolution IV and Central Composite Design for Optimized Removal of Tetracycline Drug Over Metal-Organic FrameworkTemplated Porous Carbon,” Molecules, 24 (10), 1887, 2019.

56. TRAN V.T., et al. MIL-53 (Fe) derived magnetic porous carbon as a robust adsorbent for the removal of phenolic compounds under the optimized conditions, J. Environ. Chem. Eng., 102902, 2019.

57. MOHAMMADI R., MOHAMMADIFAR M.A., MORTAZAVIAN A.M., ROUHI M., GHASEMI J.B., 
DELSHADIAN Z. Extraction optimization of pepsinsoluble collagen from eggshell membrane by response surface methodology (RSM), Food Chem., 190, 186, 2016.

58. BELWAL T., DHYANI P., BHATT I.D., RAWAL R.S., PANDE V., Optimization extraction conditions for improving phenolic content and antioxidant activity in Berberis asiatica fruits using response surface methodology (RSM), Food Chem., 207, 115, 2016.

59. TRAN V.T., et al. A hollow mesoporous carbon from metal-organic framework for robust adsorbability of ibuprofen drug in water, R. Soc. Open Sci., 6, 190058, 2019.

60. TRAN V.T., et al. Activated Carbon via. Pyropysis of Tea Industry Waste Biochar with $\mathrm{KOH}$ Activation: Preparation and Characterization, J. Eng. Appl. Sci., 14, 1755, 2019.

61. PHAM T.V., et al. The Preparation and Characterization of Expanded Graphite via Microwave Irradiation and Conventional Heating for the Purification of Oil Contaminated Water, J. Nanosci. Nanotechnol., 19 (2), 1122, 2019.

62. KANG D., et al. Performance and mechanism of $\mathrm{Mg} / \mathrm{Fe}$ layered double hydroxides for fluoride and arsenate removal from aqueous solution, Chem. Eng. J., 228, 731, 2013.

63. TRAN V.T., NGUYEN D.T., HO V.T.T., HOANG P.Q.H., BUI P.Q., BACH L.G. Efficient removal of Ni2 ions from aqueous solution using activated carbons fabricated from rice straw and tea waste, J. Mater. Environ. Sci., 8 (2), 426, 2017.
64. TRAN V.T., et al., Efficient removal of $\mathrm{Ni}^{2+}$ ions from aqueous solution using activated carbons fabricated from rice straw and tea waste, J. Mater. Environ. Sci., 8, (2), 426, 2017.

65. PAVAN F.A., DIAS S.L.P., LIMA E.C., BENVENUTTI E.V. Removal of Congo red from aqueous solution by anilinepropylsilica xerogel, Dyes and Pigments, 76 (1), 64, 2008.

66. VIMONSES V., LEI S., JIN B., CHOW C.W.K., SAINT C. Kinetic study and equilibrium isotherm analysis of Congo Red adsorption by clay materials, Chem. Eng. J., 148 (2-3), 354, 2009.

67. AKL M.A., YOUSSEF A.M., AL-AWADHI M.M. Adsorption of acid dyes onto bentonite and surfactantmodified bentonite, J. Anal. Bioanal. Tech, 4 (4), 3, 2013.

68. MALL I.D., SRIVASTAVA V.C., AGARWAL N.K., MISHRA I.M. Removal of congo red from aqueous solution by bagasse fly ash and activated carbon: kinetic study and equilibrium isotherm analyses, Chemosphere, 61 (4), 492, 2005.

69. TOR A., CENGELOGLU Y. Removal of congo red from aqueous solution by adsorption onto acid activated red mud, Journal of Hazardous Materials, 138 (2), 409, 2006.

70. NAMASIVAYAM C., KAVITHA D. Removal of Congo Red from water by adsorption onto activated carbon prepared from coir pith, an agricultural solid waste, Dye. Pigment., 54 (1), 47, 2002. 
